\title{
Preparation, Microstructure, and Mechanical Properties of Spinel-Corundum-Sialon Composite Materials from Waste Fly Ash and Aluminum Dross
}

\author{
Juntong Huang, ${ }^{1}$ Minghao Fang, ${ }^{1}$ Zhaohui Huang, ${ }^{1}$ Yan'gai Liu, ${ }^{1}$ Jingzhou Yang, \\ Saifang Huang, ${ }^{1}$ Youguo Xu, ${ }^{1}$ Kai Chen, ${ }^{1}$ Shuai Yi, ${ }^{1}$ and Shaowei Zhang ${ }^{2}$ \\ ${ }^{1}$ School of Materials Science and Technology, China University of Geosciences, Beijing 100083, China \\ ${ }^{2}$ College of Engineering, Mathematics and Physical Sciences, University of Exeter, Exeter EX4 4QF, UK
}

Correspondence should be addressed to Zhaohui Huang; huang118@cugb.edu.cn and Shaowei Zhang; s.zhang@exeter.ac.uk

Received 27 November 2013; Accepted 5 December 2013; Published 30 January 2014

Academic Editor: Filippo Berto

Copyright (C) 2014 Juntong Huang et al. This is an open access article distributed under the Creative Commons Attribution License, which permits unrestricted use, distribution, and reproduction in any medium, provided the original work is properly cited.

\begin{abstract}
The solid wastes fly ash and aluminum dross were used to prepare the low cost, high added-value product spinel-corundumSialon with an in situ aluminothermic reduction-nitridation reaction. The effects of varying raw material components and heating temperatures on the phase compositions, microstructure, bulk density, apparent porosity, and bending strength of products were investigated. The presence of hazardous or impure elements in the products was also evaluated. The sintered materials mainly consisted of micro-/nanosized plate corundum, octahedral spinel, and hexagonal columnar $\beta$-Sialon. The bulk density and bending strength of product samples initially increased and then decreased as $\mathrm{Al}$ content increased. Product samples with an Al content exceeding 10 mass $\%$ that were sintered at $1450^{\circ} \mathrm{C}$ exhibited the highest bending strength $(288 \mathrm{MPa})$, the lowest apparent porosity (1.24\%), and extremely low linear shrinkage (0.67\%). The main impurity present was $\mathrm{Fe}_{5} \mathrm{Si}_{3}$ with hazardous elements $\mathrm{P}, \mathrm{Cr}, \mathrm{Mn}$, and $\mathrm{Ni}$ doping. This work could provide a new method to reduce environmental pollution and manufacture low cost high performance refractory materials using the abundant waste materials fly ash and aluminum dross.
\end{abstract}

\section{Introduction}

The recycling of industrial solid wastes is gaining importance as the need for environmental protection increases. Fly ash is a product of the high temperature combustion of coal at fired power stations. It is captured from the exhaust of the boiler [1, 2]. Most fly ashes are primarily composed of aluminosilicates with a small amount of impurity elements, such as $\mathrm{Fe}, \mathrm{Ca}$, $\mathrm{Mg}, \mathrm{Na}, \mathrm{K}$, and S [3], as well as a trace amount of toxic heavy metal elements, including $\mathrm{Pb}, \mathrm{Zn}, \mathrm{Hg}, \mathrm{Cd}, \mathrm{Ni}$, and $\mathrm{Cr}$ [4]. Aluminum dross is a residual waste material formed on the surface of molten $\mathrm{Al}$ in the furnace during primary and secondary $\mathrm{Al}$ fusion. Apart from aluminum metal, aluminum dross normally contains other compounds (e.g., $\mathrm{Al}_{2} \mathrm{O}_{3}, \mathrm{MgO}$, $\mathrm{AlN}, \mathrm{NaCl}$, and $\mathrm{KCl}$ ) and impure or noxious elements (e.g., $\mathrm{Fe}, \mathrm{Ca}, \mathrm{Ti}, \mathrm{Cr}, \mathrm{P}, \mathrm{Cu}$, and $\mathrm{Mn}$ ) [5, 6]. Worldwide, coal-fired power stations annually produce approximately 600 million tons of fly ash [7] and the aluminum industry over 4.5 million tons of aluminum dross [6]. The majority of fly ash and aluminum dross are disposed of in landfills, resulting in leaching of toxic metal ions into soils, surface water, and even groundwater $[8,9]$.

Fly ash and aluminum dross are utilized as recycled materials in engineering and agriculture in order to reduce the environmental burden and enhance the economic benefit. They are used in industry as a raw material to prepare nonaerated concrete, concrete bricks, and filler in asphalt. In agriculture, they are employed to produce soil amendments, fertilizer, cattle feeders, and agricultural pipes [10-12]. However, the dominant waste management option employs direct land filling, especially in China. It is necessary and urgent to increase the use of fly ash and aluminum dross in high valueadded products with an easy, effective, and economically affordable method.

Up to now, many valuable products have been synthesized using fly ash or aluminum dross, including mullite [13], 
TABLE 1: Chemical compositions of fly ash and aluminum dross as determined by XRF analysis (mass\%).

\begin{tabular}{lcccccccccccccc}
\hline Component & $\mathrm{Al}_{2} \mathrm{O}_{3}$ & $\mathrm{SiO}_{2}$ & $\mathrm{MgO}$ & $\mathrm{Fe}_{2} \mathrm{O}_{3}$ & $\mathrm{CaO}$ & $\mathrm{TiO}_{2}$ & $\mathrm{Na}_{2} \mathrm{O}$ & $\mathrm{K}_{2} \mathrm{O}$ & $\mathrm{SO}_{3}$ & $\mathrm{Cr}_{2} \mathrm{O}_{3}$ & $\mathrm{MnO}$ & $\mathrm{CuO}$ & $\mathrm{Others}$ & $\mathrm{LOI}$ \\
\hline Fly ash & 40.37 & 52.45 & 0.54 & 2.36 & 0.75 & 1.52 & 0.12 & 0.21 & 0.13 & - & - & - & - & 1.56 \\
Aluminum dross & 69.60 & 5.90 & 7.10 & 4.00 & 2.80 & 1.60 & 2.60 & 0.56 & 0.50 & 0.23 & 0.50 & 0.86 & 3.43 & 0.32 \\
\hline
\end{tabular}

cordierite [14], zeolite [15], and $(\mathrm{Mg}, \mathrm{Si}) \mathrm{Al}_{2} \mathrm{O}_{4}$ [5]. $\beta$-Sialon $\left(\mathrm{Si}_{6-\mathrm{z}} \mathrm{Al}_{\mathrm{z}} \mathrm{O}_{\mathrm{z}} \mathrm{N}_{8-\mathrm{z}}\right.$ with $\left.0<z \leq 4.2\right)$ is the solid solution formed by equivalent substitution of $\mathrm{Si}$ and $\mathrm{N}$ in $\beta-\mathrm{Si}_{3} \mathrm{~N}_{4}$ by $\mathrm{Al}$ and $\mathrm{O}$, respectively [16]. Sialon-based materials have excellent mechanical, chemical, and thermal properties and are used as high temperature engineering materials, cutting tools, and abrasive materials $[17,18]$. Their application, however, has always been limited by the high cost of high purity raw materials. To overcome this drawback, many researches were devoted to synthesize Sialon using low cost sources of aluminosilicates, including clay [19], zeolite [20], and slag [21], as well as fly ash [22] and aluminum dross [23] via the carbothermal reduction and nitridation (CRN) method. The CRN method, however, has many disadvantages. It is difficult to precisely regulate the phase compositions of the product, due to variations in the partial pressure of the formed gas $\mathrm{CO}$. The shape and dimension of the product are hard to control due to the large linear shrinkage. The product is very fragile and the strength is very low. The CRN method is associated with the emission of the toxic gas $\mathrm{CO}$ and the greenhouse gas $\mathrm{CO}_{2}$.

Aluminum dross contains a large amount of metallic $\mathrm{Al}$, which can be used as a reducing agent. Herein, we advance the concept of the collaborative use of waste resources. Since fly ash contains highly reactive $\mathrm{SiO}_{2}$ and $\mathrm{Al}_{2} \mathrm{O}_{3}$ and aluminum dross contains $\mathrm{Al}_{2} \mathrm{O}_{3}, \mathrm{AlN}$, and $\mathrm{MgO}$, it is possible to design and tailor the spinel-corundum-Sialon composite refractories only using fly ash and aluminum dross as raw materials without introducing carbon. The spinel could be synthesized via the solid-state reaction of $\mathrm{MgO}$ and $\mathrm{Al}_{2} \mathrm{O}_{3}$ and Sialon by in situ aluminothermic reduction-nitridation (ARN) reaction of $\mathrm{SiO}_{2}, \mathrm{Al}_{2} \mathrm{O}_{3}$, and $\mathrm{AlN}$ in a nitrogen atmosphere at high temperature. To date, there has been little study of the hazardous or impure elements in the final products although impurity is an important obstacle for the utilization of industrial wastes.

The purpose of the study was to efficiently utilize the solid wastes fly ash and aluminum dross in the preparation of highly value-added spinel-corundum-Sialon composites. The manufacturing process was optimized by investigating the phase composition, microstructure, physicomechanical properties, and the presence of hazardous or impure elements in the final product. The spinel-corundum-Sialon composite product can be used as structural refractory materials. It is a very low cost and environmentally friendly method for manufacturing high performance refractories products from waste materials.

\section{Materials and Methods}

The fly ash used in this work was provided by the Shuozhou Electric Power Development Co., Ltd. in Shanxi Province,
China. The aluminum dross was obtained from the aluminum recycling company, Shanghai Sigma Metals Inc. The chemical composition of fly ash and aluminum dross was determined using X-ray fluorescence (XRF, Magix PW2403, Panalytical, Holland) (Table 1). The main crystalline phase of fly ash was mullite. Some amorphous glass phase was also present. The aluminum dross consisted of $\mathrm{Al}, \mathrm{Al}_{2} \mathrm{O}_{3}$, AlN, quartz, $\mathrm{NaCl}, \mathrm{KCl}$, and a small amount of glass phase. The particle size of the fly ash and aluminum dross was less than $74 \mu \mathrm{m}$. The principle of stoichiometric ingredient is that according to the contents of the metallic Al in aluminum dross, $\mathrm{SiO}_{2}$ in fly ash and aluminum dross is reduced by the metallic $\mathrm{Al}$ and totally transformed to $\mathrm{Si}_{3} \mathrm{~N}_{4}$, which subsequently reacted with $\mathrm{Al}_{2} \mathrm{O}_{3}$ and $\mathrm{AlN}$ to form Sialon. Herein, this work performed the stoichiometric composition of 41.23 mass\% fly ash (FA) and 58.77 mass\% aluminum dross (AD), and other series with exceeding 10 mass\% (38.94 mass\% FA, 61.06 mass $\%$ AD), 50 mass $\%$ (31.87 mass\% FA, 68.13 mass $\%$ $\mathrm{AD}$ ), and 100 mass\% (25.97 mass\% FA, 74.03 mass $\%$ AD) of the metallic $\mathrm{Al}$ in the aluminum dross were also investigated.

Fly ash and aluminum dross powders were ball-milled together for $2 \mathrm{~h}$ and passed through a 200-mesh sieve. The mixture was pressed into compact bars $(45 \mathrm{~mm} \times 6 \mathrm{~mm} \times$ $6 \mathrm{~mm}$ ) with $8 \mathrm{wt}$.\% polyvinyl alcohol (PVA) under a pressure of $50 \mathrm{MPa}$ for $30 \mathrm{~s}$. The green bodies were compressed using an isostatic pressure of $200 \mathrm{MPa}$ for $60 \mathrm{~s}$. The bars were dried at $80^{\circ} \mathrm{C}$ for $6 \mathrm{~h}$ in a drying oven and then placed in a graphite crucible and heated in flow nitrogen (purity 99.99\%) in a graphite furnace at 1350,1450 , and $1550^{\circ} \mathrm{C}$ for $3 \mathrm{~h}$, respectively. The corresponding raw material powders were chosen as the packing powders in order to prevent deformation of the product bars. All the samples were cooled down naturally.

The crystalline phases were examined via X-ray diffractometer (XRD, XD-3, China), using $\mathrm{Cu} K \alpha 1$ radiation $(\lambda=$ $1.5406 \AA$ ) with a step of $0.02^{\circ}(2 \theta)$ and a scanning rate of $4^{\circ} \mathrm{min}^{-1}$. Semiquantitative analysis of the crystalline phase content was based on calibration curves determined from the relative intensity of the diffraction peaks of (311) spinel, (113) $\mathrm{Al}_{2} \mathrm{O}_{3}$, and $(020) \beta$-Sialon $[24,25]$. The shrinkage percent in the width direction of the sintered samples was measured using a vernier caliper. The bulk density and apparent porosity were measured in water using a conventional method, according to Archimedes' principle. The bending strength was determined using a conventional three-point bending method. The microstructure and morphology of products were observed using a scanning electron microscope (SEM, JSM-6460, Japan, XL30 ESEM-TMP) equipped with an energy dispersive spectroscopy detector (EDS, Philips-FEI) and a high-resolution transmission electron microscope (HRTEM, JEOL JEM-2100, Phillips) with EDS (Oxford INCA). Product samples were held with a copper grid and 


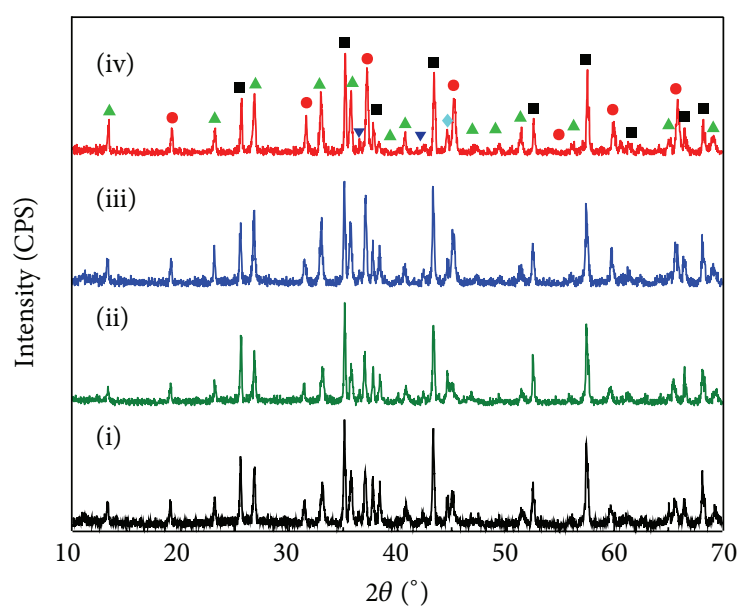

(a)

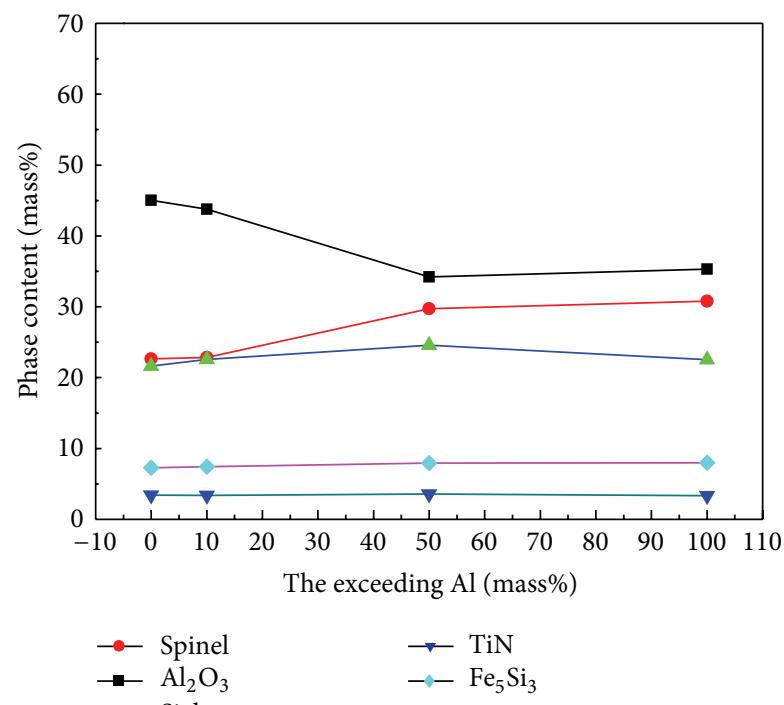

(c)

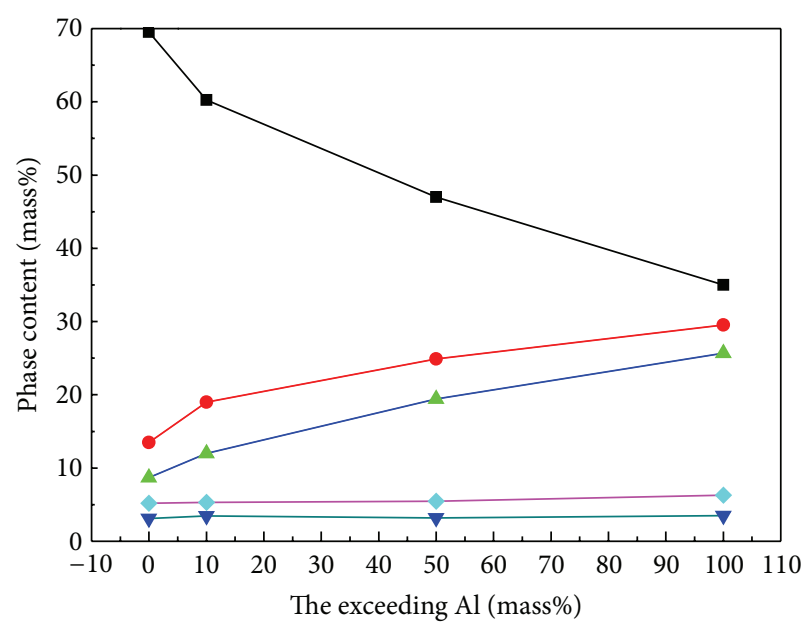

(b)

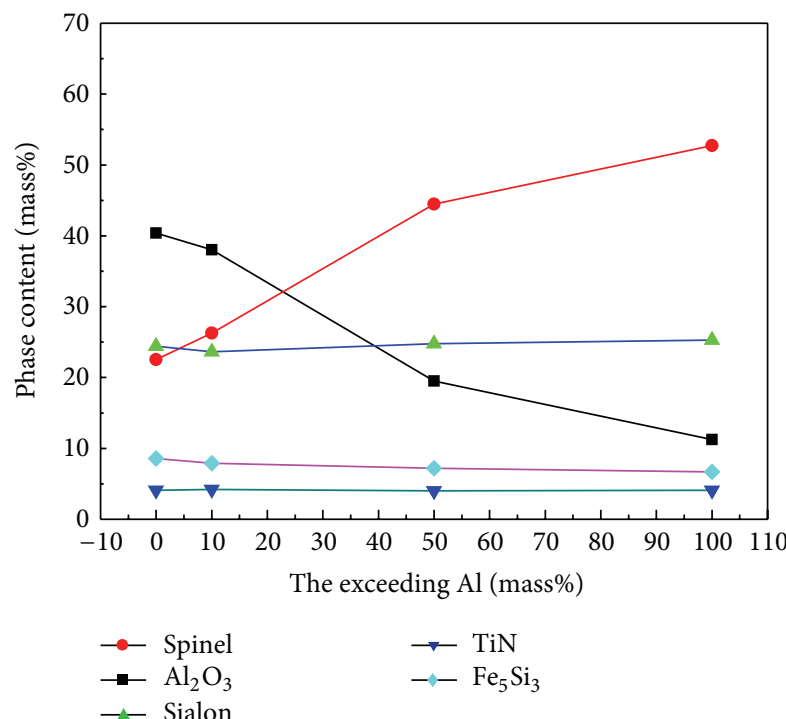

(d)

FIGURE 1: Phase assemblages of products. (a) XRD patterns of samples sintered at $1450^{\circ} \mathrm{C}$ with the exceeding metallic $\mathrm{Al}$ of (i) 0 mass $\%$, (ii) 10 mass\%, (iii) 50 mass\%, and (iv) 100 mass\%. Dependence of product phase content on content of the exceeding $\mathrm{Al}$ in aluminum dross sintered at different temperatures (b) $1350^{\circ} \mathrm{C}$, (c) $1450^{\circ} \mathrm{C}$, and (d) $1550^{\circ} \mathrm{C}$.

coated with carbon to improve the electrical conductivity prior to TEM observation.

\section{Results}

3.1. Characterization of Phase Assemblages and Product Microstructures. The crystalline phases of the product samples sintered at different temperatures were determined with XRD. They were mainly comprised of the same kinds of phase assemblages, that is, corundum, spinel, and Sialon, along with some minor phases such as $\mathrm{TiN}$ and $\mathrm{Fe}_{5} \mathrm{Si}_{3}$. The typical pattern of samples sintered at $1450^{\circ} \mathrm{C}$ with various exceeding metallic $\mathrm{Al}$ is shown in Figure 1(a). The phase content of products sintered at different temperatures was calculated and plotted in Figures $1(\mathrm{~b})-1(\mathrm{~d})$. At $1350^{\circ} \mathrm{C}$ (Figure 1(b)), with a stoichiometric addition of $\mathrm{Al}$, the final products were mainly corundum (69.5 mass\%) with a small amount of spinel $\left(\mathrm{MgAl}_{2} \mathrm{O}_{4}, 13.5\right.$ mass\%) and Sialon $\left(\mathrm{Si}_{3} \mathrm{Al}_{3} \mathrm{O}_{3} \mathrm{~N}_{5}, 8.7\right.$ mass\%). As the amount of $\mathrm{Al}$ was increased, the amount of spinel and $\beta$-Sialon increased and corundum dramatically decreased. At $1450^{\circ} \mathrm{C}$ (Figure $1(\mathrm{c})$ ), the products from a stoichiometric feed ratio of $\mathrm{Al}$ consisted of 45.1 mass\% corundum, 22.7 mass\% spinel, and 21.6 mass\% Sialon. As the amount of $\mathrm{Al}$ was increased, the trend of phase content was similar to that at $1350^{\circ} \mathrm{C}$. At $1550^{\circ} \mathrm{C}$ (Figure $1(\mathrm{~d})$ ), an Al-rich spinel was obtained in the products (XRD not shown here) and its amount increased as $\mathrm{Al}$ content increased. There was a yield of 52.7 mass\% Al-rich spinel and 11.2 mass\% corundum in the product with the exceeding 100 mass\% Al. Herein, XRD analysis defined formula for spinel as $\mathrm{Mg}_{0.388} \mathrm{Al}_{2.408} \mathrm{O}_{4}$. The $z$-value of $\beta$-Sialon increased from 3 to 4 . 


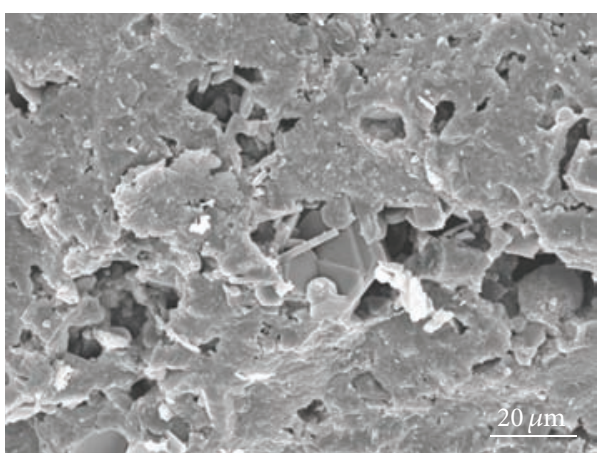

(a)

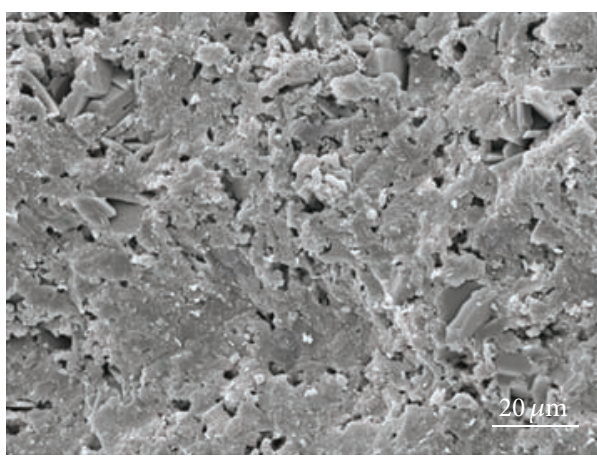

(c)

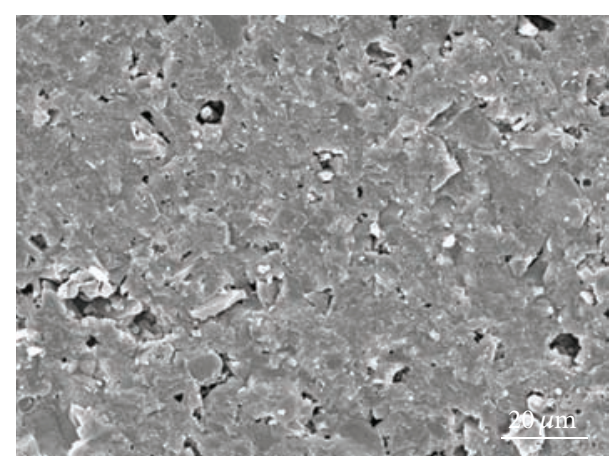

(b)

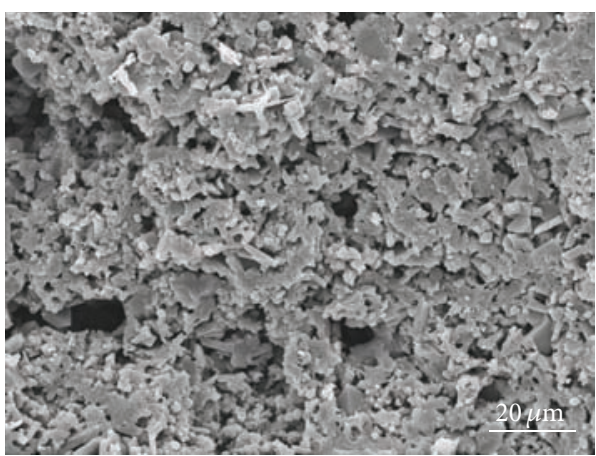

(d)

Figure 2: Product microstructure. SEM images of samples sintered at $1450^{\circ} \mathrm{C}$ with exceeding $\mathrm{Al}$ of (a) 0 mass $\%$, (b) 10 mass $\%$, (c) 50 mass $\%$, and (d) 100 mass\%.

The microstructure of product samples was recorded using SEM (JSM-6460, Japan). Typical images of product sintered at $1450^{\circ} \mathrm{C}$ are shown in Figure 2. The sample with a stoichiometric amount of $\mathrm{Al}$ consisted of a large quantity of glassy phase with a certain amount of porosity, which provided sufficient space to grow plate corundum. Spinel and $\beta$-Sialon phases were not seen. As Al content exceeded 10 mass\%, the porosity decreased and the product was well sintered. With higher $\mathrm{Al}$ content, the plate $\mathrm{Al}_{2} \mathrm{O}_{3}$ and other crystal grains became apparent, the number of small micropores increased, and the amount of glassy phase (mainly consisting of $\mathrm{Al}, \mathrm{Si}$, and $\mathrm{O}$ ) decreased (further TEM and EDS evidences on this will be given below). The decreased amount of the glass phase in the product was due to the reduction of $\mathrm{SiO}_{2}$ in the starting composition of the sample. The morphology of the crystalline phases was further observed by SEM (XL30 ESEM-TMP) (Figure 3). The micrographs visualized many randomly dispersed plate corundum grains of about 5-10 $\mu \mathrm{m}$ diameter, some octahedral spinel crystals of 3-5 $\mu \mathrm{m}$ diameter, and columnar $\beta$-Sialon crystals with typical widths of $0.8-1.2 \mu \mathrm{m}$ and aspect ratios of 3-6 (Figure 3(a)). Occasionally, some $\mathrm{Al}_{2} \mathrm{O}_{3}$ grains were observed with a steplike fracture (Figure 3(c)). The impurities in the starting materials, $\mathrm{Fe}, \mathrm{Cu}, \mathrm{Mn}$, and $\mathrm{Cr}$, were alloyed into spherical particles (Figure 4(c)) which were apparent by their bright contrast (see more details in the TEM images and EDS patterns later). Prismatic $\beta$-Sialon crystals were well crystallized and intensively distributed in some regions of the sample, and a few grew in an epitaxial direction on the plate corundum (Figure 3(e)). EDS analysis (Figure 3(f)) demonstrated both $\mathrm{Ca}$ and $\mathrm{Mg}$ in $\beta$-Sialon. It is believed that $\beta$-Sialon has the capacity to incorporate a variety of metallic ions into its interstices, making multiphase materials with much lower glass content.

The morphology and microstructure of the products were further characterized by TEM and HRTEM (Figure 4). Microsized spinel, $\mathrm{Al}_{2} \mathrm{O}_{3}$, and $\beta$-Sialon grains were observed by SEM. Contiguous nanosized grains in the glassy matrix were visualized with TEM (Figures 4(a) and 4(b)). Typical TEM images, HRTEM images, and the selected area electron diffraction (SAED) pattern of $\beta$-Sialon nanograins are displayed in Figures 4(c), 4(d), and 4(e). The EDX pattern was compatible with a $\beta$-Sialon nanograin consisting of $\mathrm{Si}, \mathrm{Al}$, $\mathrm{O}$ and $\mathrm{N}$, with a small amount of $\mathrm{Mg}$ and $\mathrm{Ca}$ (Figure 4(f)). HRTEM lattice fringe image (Figure $4(\mathrm{~d})$ ) revealed $\beta$-Sialon nanograins with a hexagonal structure. The measured $d$ spacings of $0.67 \mathrm{~nm}$ and $0.38 \mathrm{~nm}$ corresponded well to the $(01 \overline{1} 0)$ and $(11 \overline{2} 0)$ planes of $\beta$-Sialon.

\subsection{The Physicomechanical Properties of Spinel-Corundum-} Sialon Composite Materials. The apparent porosity and bulk density of product samples as a function of the exceeding Al content are shown in Figure 5. The bulk density initially increased and then decreased as $\mathrm{Al}$ content increased. The opposite trend was observed for the apparent porosity. The highest bulk density of product sample, $3.15 \mathrm{~g} \cdot \mathrm{cm}^{-1}$, was seen 


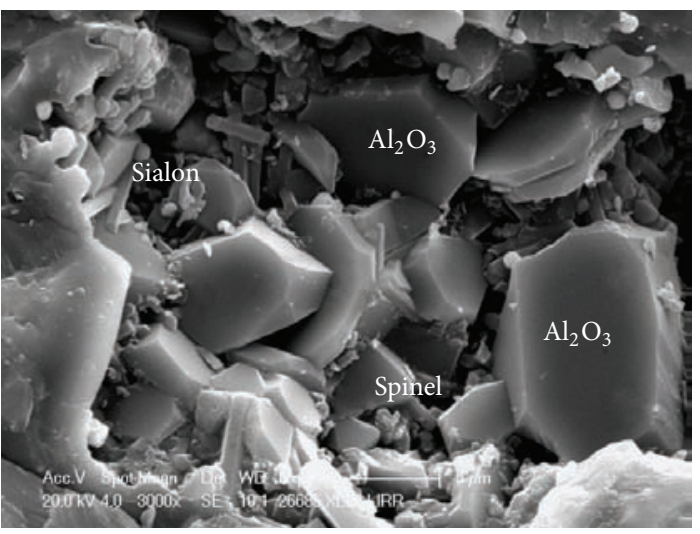

(a)

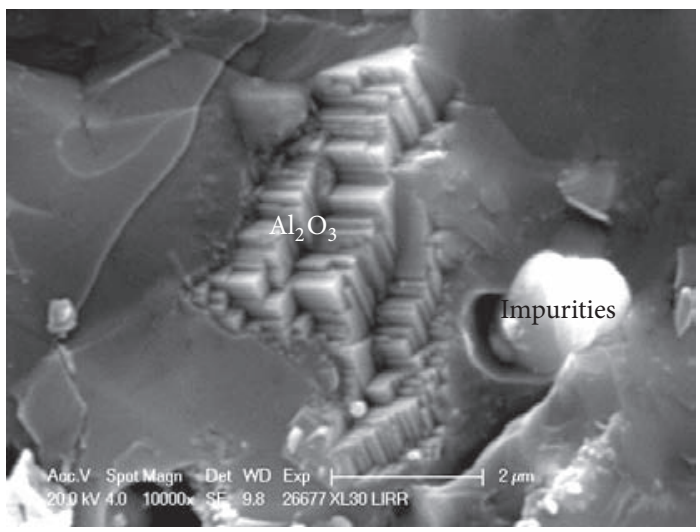

(c)

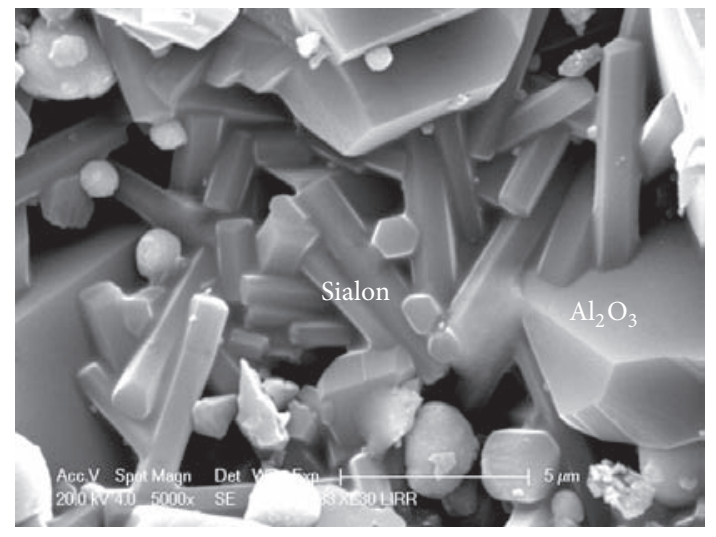

(e)

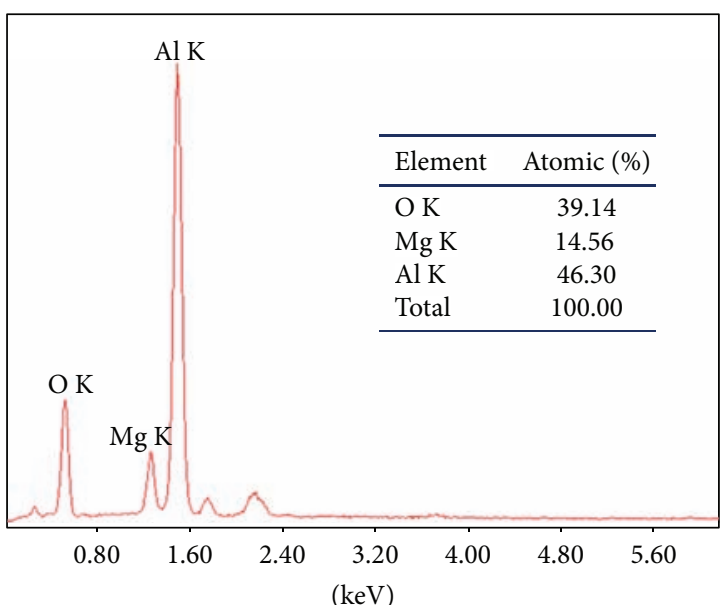

(b)

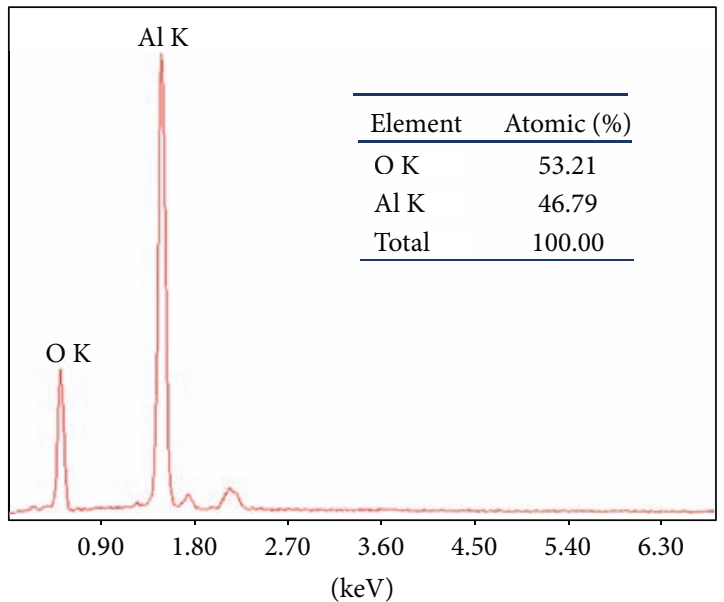

(d)

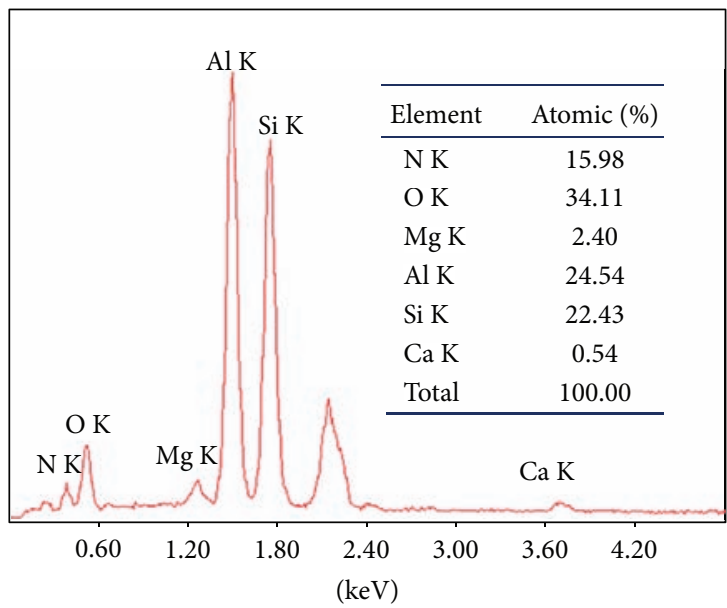

(f)

FIGURE 3: Typical SEM images and EDS results of the products sample with the exceeding metallic $\mathrm{Al}$ of 10 mass $\%$ sintered at $1450^{\circ} \mathrm{C}$. (a) SEM image of product, showing plate corundum, octahedral spinel, and columnar $\beta$-Sialon. (b) The EDS pattern of spinel. ((c), (d)) SEM image and EDS pattern of step-like corundum. ((e), (f)) SEM image and EDS pattern of columnar $\beta$-Sialon. 


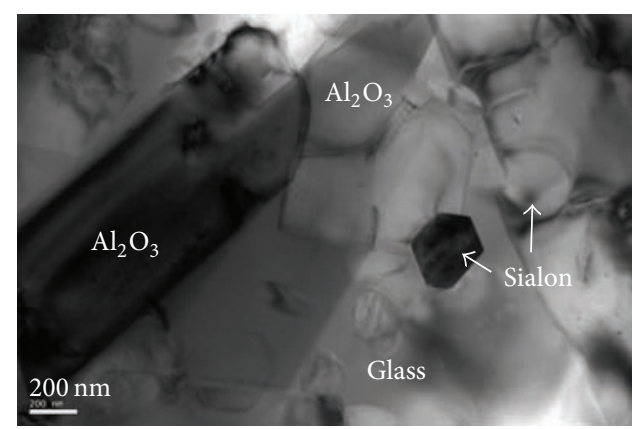

(a)

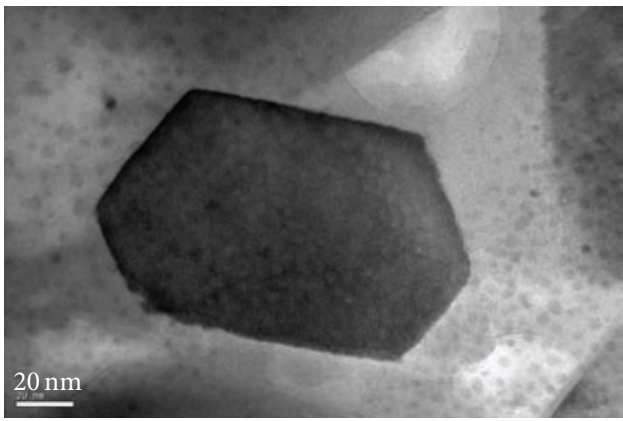

(c)

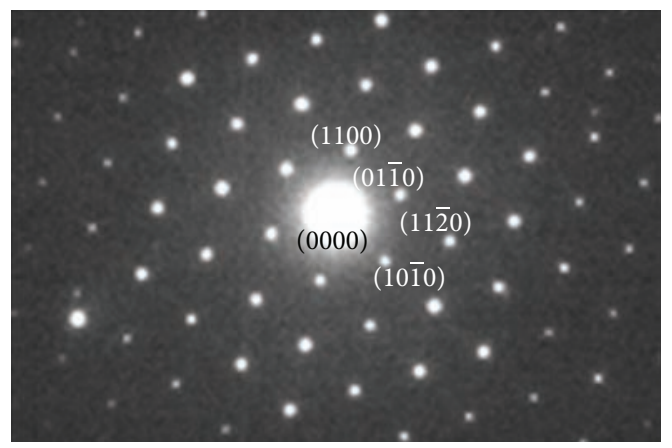

(e)

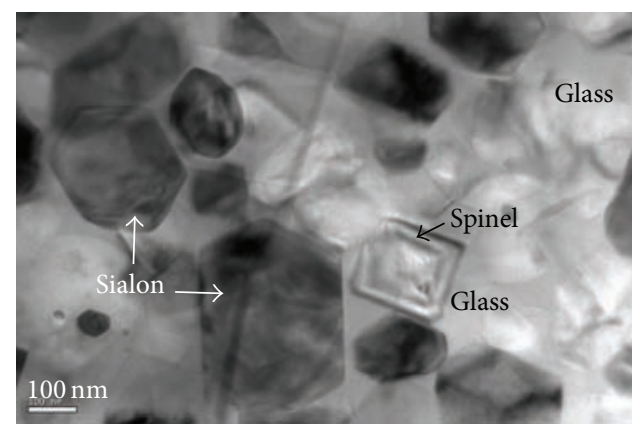

(b)

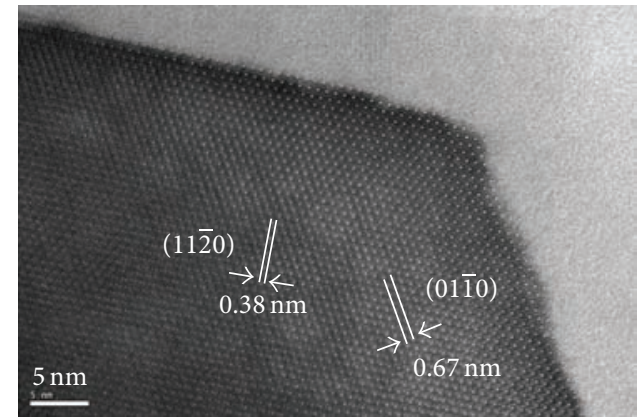

(d)

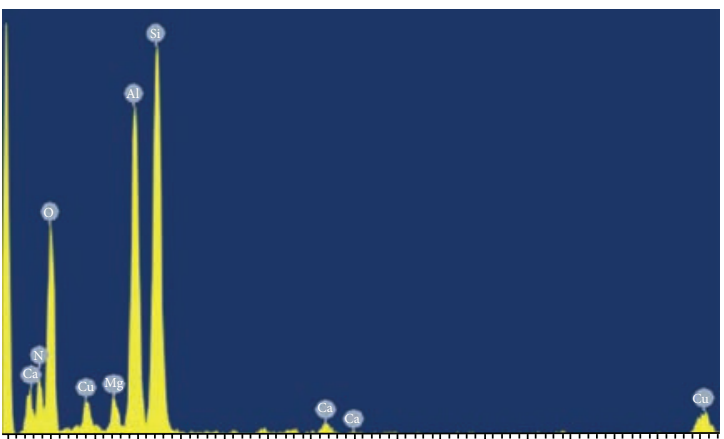

$\begin{array}{lllllllllllllllll}0 & 0.5 & 1 & 1.5 & 2 & 2.5 & 3 & 3.5 & 4 & 4.5 & 5 & 5.5 & 6 & 6.5 & 7 & 7.5 & 8\end{array}$

$(\mathrm{keV})$

(f)

Figure 4: Microstructure of products. ((a), (b)) TEM images of product samples with the exceeding metallic $\mathrm{Al}$ of 10 mass $\%$ sintered at $1450^{\circ} \mathrm{C}$. ((c)-(f)) Typical TEM, HRTEM, and SAED images and EDS patterns of Sialon nanograins in the products.

with the exceeding 10 mass $\% \mathrm{Al}$ content at $1450^{\circ} \mathrm{C}$. Therefore, the appropriately exceeding $\mathrm{Al}$ contributed to the increased density of the sample. As expected, an increase in temperature was associated with an increase in bulk density. The apparent porosity decreased and the bulk density increased as sintering temperatures increased from $1350^{\circ} \mathrm{C}$ to $1550^{\circ} \mathrm{C}$. The diffusion coefficient was related to temperature according to the formula $D=D_{0} \exp (-Q / R T)$ [26]. At low temperatures, surface diffusion governed the sintering process while body diffusion dominated it at high temperatures. However, the densification of final products only depended on body diffusion. Temperature was the primary factor affecting final product density. The amount of spinel and Sialon increased with the $\mathrm{Al}$ increasing (Figures $1(\mathrm{~b})-1(\mathrm{~d})$ ). The porosity also increased distinctly with the increase of $\mathrm{Al}$ (Figure 5(a)). This increase in $\mathrm{Al}$ could be attributed to the increased use of aluminum dross (or less fly ash) in the raw materials and resulted in a decrease in the glass phase consisting of $\mathrm{Si}, \mathrm{Al}$, and $\mathrm{O}$ (Figure 2). This revealed that the appropriate liquid phase promoted the sintering process as well as densification at high firing temperatures.

The plot of bending strength versus the amount of the exceeding $\mathrm{Al}$ at different sintering temperatures is illustrated in Figure 6 . The bending strength initially increased and subsequently decreased as $\mathrm{Al}$ content increased, at temperatures from 1350 to $1550^{\circ} \mathrm{C}$. The highest bending strength $(288 \mathrm{MPa})$ was achieved in product with the exceeding 10 mass $\% \mathrm{Al}$ sintered at $1450^{\circ} \mathrm{C}$. The product sintered at $1450^{\circ} \mathrm{C}$ had high bending strength and extremely low linear shrinkage $(0.67 \%)$. The inset in Figure 6 is a digital photo of samples sintered at $1450^{\circ} \mathrm{C}$. The samples did not bend after sintering in packing powders. Sintering in the corresponding packing powders 


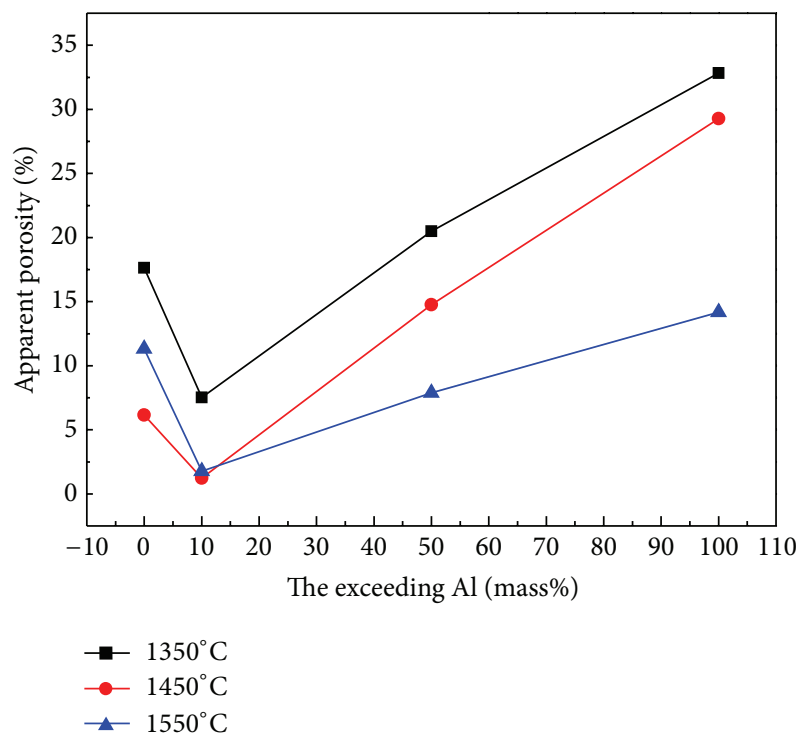

(a)

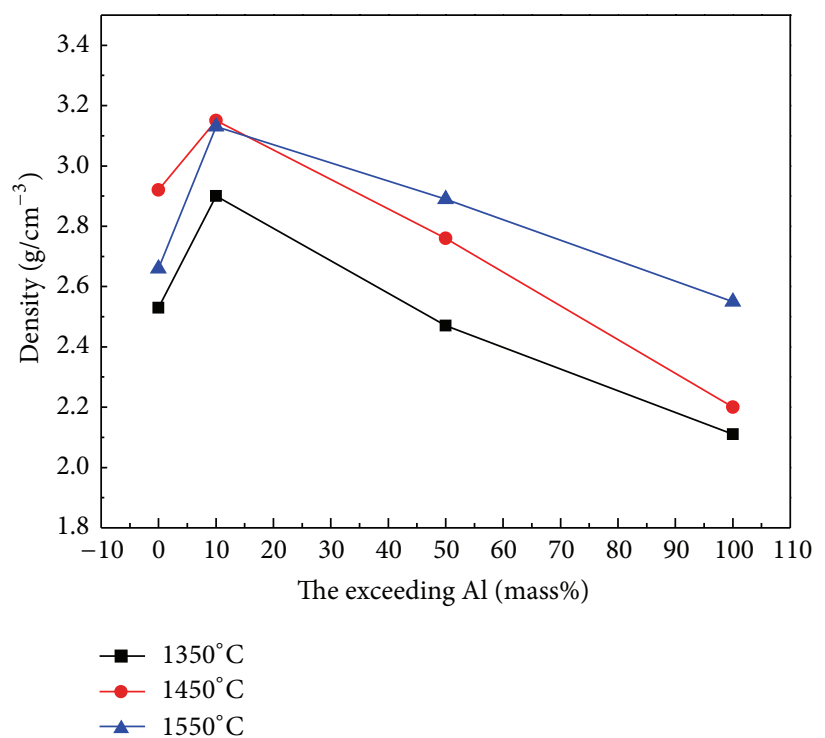

(b)

FIGURE 5: The physical properties of spinel-corundum-Sialon composite materials. (a) The apparent porosity and (b) bulk density of samples sintered at different temperatures as a function of the exceeding $\mathrm{Al}$ content.

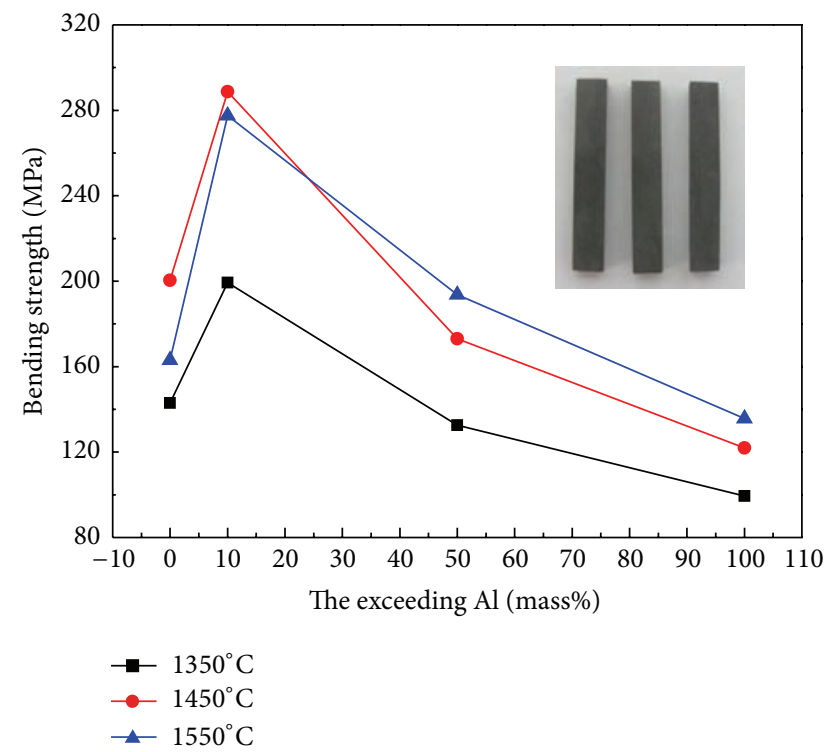

FIGURE 6: Bending strength of spinel-corundum-Sialon composite materials. The bending strength of product sintered at different temperatures as a function of the exceeding $\mathrm{Al}$ content. The inset is the digital image of product sintered at $1450^{\circ} \mathrm{C}$.

was associated with the same shrinkage rate during heating. Hence, the in situ aluminothermic reduction-nitridation of fly ash and aluminum dross with appropriate packing powders resulted in spinel-corundum-Sialon composite materials that maintained their shape during processing.

3.3. Analysis of Hazardous Impurities. Many kinds of hazardous or impure elements are present in fly ash and aluminum dross. They are another obstacle to the use of these waste materials. An analysis of these elements in the product samples was performed. Most of $\mathrm{Ca}$ cations were incorporated into $\beta$-Sialon crystals (Figures 3(f) and 4(f)). Fewer Ca cations were present in the glassy phase (Figures $7(\mathrm{a})$ and $7(\mathrm{~d})$ ), playing a key role in reducing the sintering temperature.

Figures 3(c) and 3(d) show that some aggregate impurities (shiny spheres) were embedded in the products. Their structures were further characterized by TEM, SAED, and EDS (Figure 7). Impurities were clearly seen as particles with a different (brighter) contrast. The TEM image, SAED images, and EDS patterns demonstrated that the impurities contained 35.20 at.\% $\mathrm{Si}$ and 56.76 at.\% $\mathrm{Fe}$ and that the crystalline phase was $\mathrm{Fe}_{5} \mathrm{Si}_{3}$, a hard alloy. The EDS pattern identified trace elements ( $\mathrm{P}, \mathrm{Cr}, \mathrm{Mn}$, and $\mathrm{Ni}$ ) in the $\mathrm{Fe}_{5} \mathrm{Si}_{3}$ particle. The effect these aggregates had on the spinel$\mathrm{Al}_{2} \mathrm{O}_{3}$-Sialon composites properties was examined. Cracks were seen along the grain boundary of impurity-rich $\mathrm{Fe}_{5} \mathrm{Si}_{3}$ spheres (TEM image, Figure 7(b)). These cracks could absorb fracture energy, resulting in improved fracture strength and toughness of the spinel- $\mathrm{Al}_{2} \mathrm{O}_{3}$-Sialon composites.

Chemical and foregoing EDS analysis did not identify the trace element $\mathrm{Ti}$. The product samples were carefully examined with TEM and the column-like nanograins characteristics of Ti and $\mathrm{N}$ were found (Figures 7(c) and 7(f)). XRD (Figure 1(a)), SAED, and EDS patterns (Figures 7(c) and 7(f)) revealed these nanograins to be TiN crystals.

\section{Discussion}

Using only the solid wastes of fly ash and aluminum dross as raw materials and a facile in situ aluminothermic 


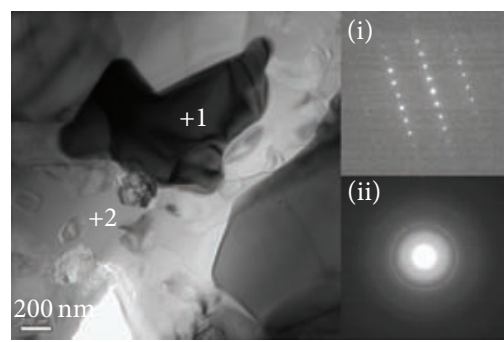

(a)

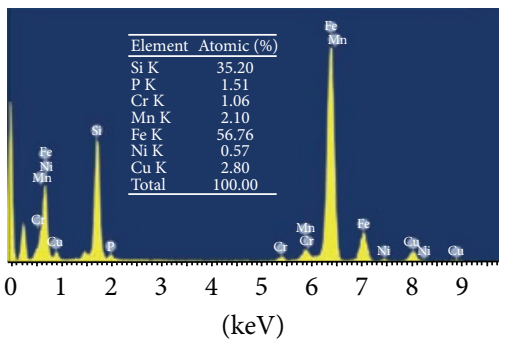

(d)

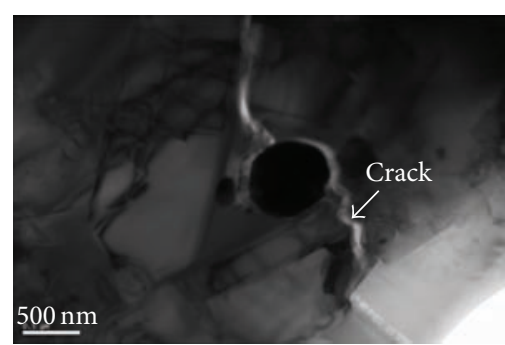

(b)

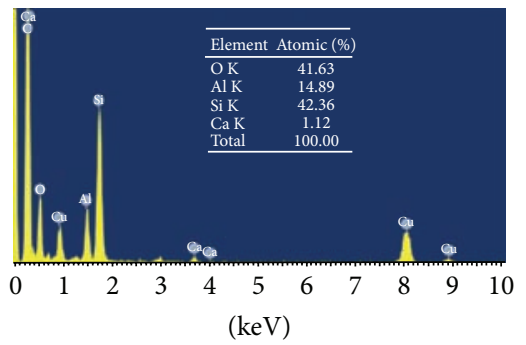

(e)

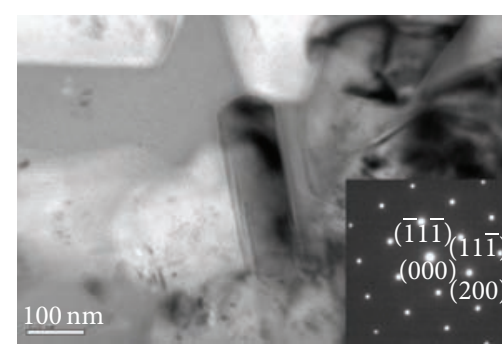

(c)

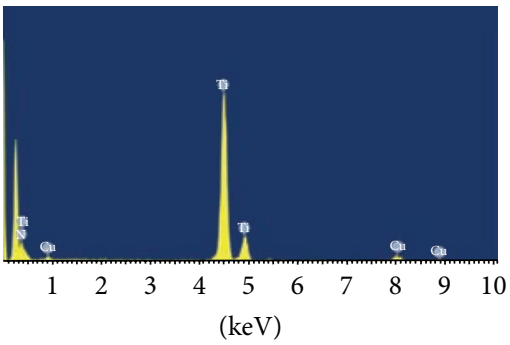

(f)

FIgURE 7: Typical TEM images, SAED images, and EDS patterns of impurities and glassy phase in the products. ((a), (b)) TEM images and $((\mathrm{d}),(\mathrm{e}))$ the EDS results of impurities and the glassy phase in zone 1 and zone 2, respectively. (i) and (ii) show the SAED patterns of impurities and glass, respectively. ((c), (f)) Typical TEM, SAED, and EDS patterns of TiN in the products.

reduction-nitridation method, we prepared valuable spinelcorundum-Sialon composite materials, confirmed by XRD results (Figure 1(a)), along with EDS (Figure 3). The metallic $\mathrm{Al}$ in the aluminum dross enhanced the formation of spinel and Sialon at low temperatures. This finding was confirmed by the phase content analysis of the products sintered at different temperatures (Figures 1(b)-1(d)). The amount of spinel was increased due to the increase of $\mathrm{MgO}$ and $\mathrm{Al}_{2} \mathrm{O}_{3}$, while for Sialon it was produced due to the increased $\mathrm{Al}$ content. The aluminothermic reduction-nitridation reaction was exothermic [27], and the increased $\mathrm{Al}$ content resulted in the resultant increase in temperature. This increase in temperature also facilitated the formation of Sialon. Increasing the reaction temperature increased the production of spinel and Sialon and formed Al-rich spinel with a higher $z$-value Sialon. SEM (Figures 2 and 3) and TEM (Figure 4) images revealed that spinel-corundum-Sialon composite materials were composed of not only microsized, but also nanosized spinel, $\mathrm{Al}_{2} \mathrm{O}_{3}$, and $\beta$-Sialon grains. The in situ grown nanograins would increase the fracture strength of the $\beta$ Sialon multiphase materials. In addition, as a hard and wearresistive material $[28,29]$, TiN, the content of which basically had no variation in the product samples, can serve to improve the strength and wear resistance of the spinel- $\mathrm{Al}_{2} \mathrm{O}_{3}$-Sialon composites.

Only two nitrides, Sialon and TiN, were produced during the aluminothermic reduction-nitridation reaction. Their possible reaction mechanisms are proposed below, along with the underlying thermodynamic calculations [30]:

$$
\begin{gathered}
2 \mathrm{Al}(\mathrm{l})+\mathrm{N}_{2}(\mathrm{~g})=2 \mathrm{AlN}(\mathrm{s}), \\
\Delta_{r} G_{1}=-652.954+0.2328 T-0.0191 T \lg \left(\frac{P_{\mathrm{N}_{2}}}{P^{\theta}}\right),
\end{gathered}
$$

$$
\begin{gathered}
4 \mathrm{Al}(\mathrm{l})+3 \mathrm{SiO}_{2}(\mathrm{~s})=3 \mathrm{Si}(\mathrm{s})+2 \mathrm{Al}_{2} \mathrm{O}_{3}(\mathrm{~s}), \\
\Delta_{r} G_{2}=-675.922+0.1591 T, \\
3 \mathrm{Si}(\mathrm{s})+2 \mathrm{~N}_{2}(\mathrm{~g})=\mathrm{Si}_{3} \mathrm{~N}_{4}(\mathrm{~s}), \\
\Delta_{r} G_{3}=-722.836+0.3150 T-0.0382 T \operatorname{Tg}\left(\frac{P_{\mathrm{N}_{2}}}{P^{\theta}}\right), \\
\mathrm{Si}_{3} \mathrm{~N}_{4}(\mathrm{~s})+\mathrm{Al}_{2} \mathrm{O}_{3}(\mathrm{~s})+\mathrm{AlN}(\mathrm{s})=\mathrm{Si}_{3} \mathrm{Al}_{3} \mathrm{O}_{3} \mathrm{~N}_{5}(\mathrm{~s}), \\
\Delta_{r} G_{4}=-83.887+0.018 T .
\end{gathered}
$$

Mullite is a crystalline phase found in the fly ash. Its decomposition reaction and Gibbs free energy $\left(\Delta_{r} G\right)$ are

$$
\begin{gathered}
3 \mathrm{Al}_{2} \mathrm{O}_{3} \cdot 2 \mathrm{SiO}_{2}(\mathrm{~s})=3 \mathrm{Al}_{2} \mathrm{O}_{3}(\mathrm{~s})+2 \mathrm{SiO}_{2}(\mathrm{~s}), \\
\Delta_{r} G_{5}=-8.6+0.0174 \mathrm{~T} .
\end{gathered}
$$

When the temperature was higher than $494.0 \mathrm{~K}, \Delta_{r} G_{5}$ was greater than 0 , and mullite did not easily decompose to $\mathrm{Al}_{2} \mathrm{O}_{3}$ and $\mathrm{SiO}_{2}$. The mullite reacted directly with $\mathrm{Al}$ and $\mathrm{N}_{2}$ to form Sialon as

$$
\begin{gathered}
3\left(3 \mathrm{Al}_{2} \mathrm{O}_{3} \cdot 2 \mathrm{SiO}_{2}\right)(\mathrm{s})+10 \mathrm{Al}(\mathrm{l})+5 \mathrm{~N}_{2}(\mathrm{~g}) \\
=2 \mathrm{Si}_{3} \mathrm{Al}_{3} \mathrm{O}_{3} \mathrm{~N}_{5}(\mathrm{~s})+11 \mathrm{Al}_{2} \mathrm{O}_{3}(\mathrm{~s}), \\
\Delta_{r} G_{6}=-3648.940+1.2382 T-0.0955 T \operatorname{Tg}\left(\frac{P_{\mathrm{N}_{2}}}{P^{\theta}}\right) .
\end{gathered}
$$




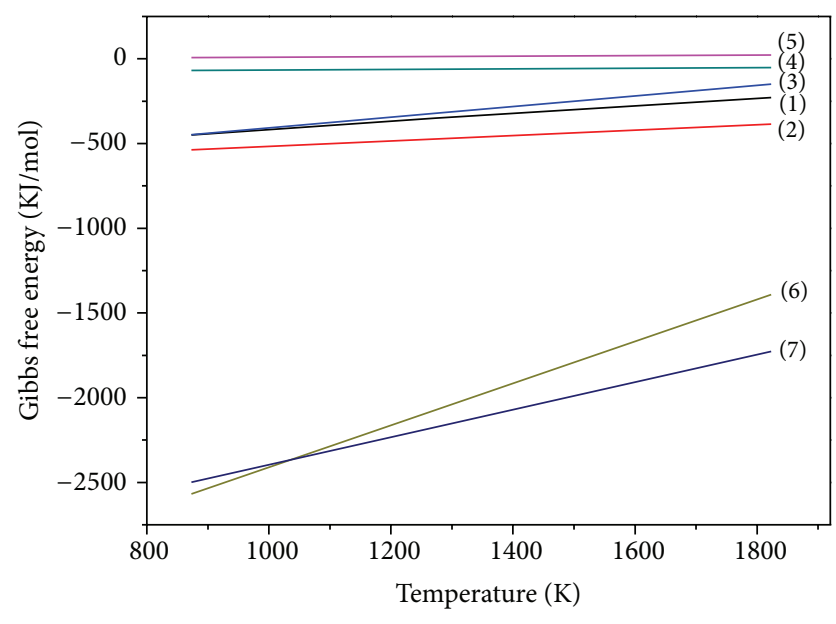

FIGURE 8: Gibbs free energy of reaction $\left(\Delta_{r} G\right)$ versus temperature $(T)$ for reactions (1) through (13). Under the experimental conditions of this study, all the above reaction equations could occur except (9).

The formation of TiN could be explained by reaction (13) through the aluminothermic reduction-nitridation process:

$$
\begin{gathered}
6 \mathrm{TiO}_{2}(\mathrm{~s})+8 \mathrm{Al}(\mathrm{l})+3 \mathrm{~N}_{2}(\mathrm{~g}) \longrightarrow 6 \mathrm{TiN}(\mathrm{s})+4 \mathrm{Al}_{2} \mathrm{O}_{3}(\mathrm{~s}) \\
\Delta_{r} G_{7}=-3209.88+0.8137 \mathrm{~T}-0.0573 \mathrm{Tlg}\left(\frac{P_{\mathrm{N}_{2}}}{P^{\theta}}\right) .
\end{gathered}
$$

High purity nitrogen gas $(\geq 99.999 \%)$ at a pressure of $0.1 \mathrm{MPa}$ was used during synthesis. The pressure of $\mathrm{N}_{2}$ was $P_{\mathrm{N}_{2}} / P^{\theta} \approx 1$. The Gibbs free energy of reaction $\left(\Delta_{r} G\right)$ for (1) through (13) at different temperatures $(T)$ was calculated (Figure 8). Under the experimental conditions of this study, all the above reactions could occur except (9). The reaction pathway for the formation of Sialon could be through route 1 , that is, $((1)+(3)+(5)+(7))$, and/or route 2 , that is, (11). The $\beta$ Sialon product was surrounded by glassy phase (Figure 4(c)), and its formation might occur in a liquid phase via solutiondiffusion-nucleation-reprecipitation, as previously reported by Cai et al. [31].

The bending strength of the spinel-corundum-Sialon composite materials was dependent on the composition of the raw materials and the testing temperature. These two factors had a remarkable effect on the content of the liquid phase, microstructure, apparent porosity, and bending strength of the products. The relationship between the bending strength and apparent porosity of the spinel-corundum-Sialon composites was absolutely in agreement with the exponential equation of the strength-porosity dependence [32], $\sigma=$ $\sigma_{0} \exp (-n p)$, where the mechanical strength of inorganic nonmetallic materials usually decreases with an increase in porosity. An interesting result of this study was that the highest bending strength $(288 \mathrm{MPa})$ of the spinel-corundumSialon composites was achieved at the exceeding 10 mass $\%$ $\mathrm{Al}$ after being sintered at $1450^{\circ} \mathrm{C}$ rather than $1550^{\circ} \mathrm{C}$. This may be attributed to more liquid phase formed at the lower temperature, which resulted in a larger amount of spinel and
Sialon (Figures 1(c) and 1(d)). Although the liquid phase itself did not enhance the mechanical strength of the products, it did facilitate bulk sintering [27]. These findings suggest that the mechanical properties depend on a combination of the sintering temperature and amount of liquid phase.

Most of the hazardous or impure elements found in the fly ash and aluminum dross were found in the products. A few impurities such as $\mathrm{NaCl}$ and $\mathrm{KCl}$ from aluminum dross and $\mathrm{Na}_{2} \mathrm{O}$ and $\mathrm{K}_{2} \mathrm{O}$ from fly ash were not present in the products. The boiling point of these salts is about $1450^{\circ} \mathrm{C}$ and the sublimation point of these oxides is less than $1300^{\circ} \mathrm{C}$ [33], so these impurities would evaporate during sintering. The volatiles that leave the reaction furnace during sintering can be collected in order to minimize environmental pollution.

\section{Conclusions}

Low cost spinel-corundum-Sialon composite materials were prepared from fly ash and aluminum dross by in situ aluminothermic reduction-nitridation (ARN) at relatively low sintering temperatures. The product composites mainly consisted of micro-/nanosized plate corundum, octahedral spinel, and hexagonal columnar $\beta$-Sialon. As Al content increased (i.e., use of the aluminum dross), the bending strength and bulk density of sintered products initially increased and subsequently decreased. The apparent porosity exhibited an opposite trend. Samples with an exceeding 10 mass\% $\mathrm{Al}$ (i.e., 38.94 mass\% fly ash, 61.06 mass\% aluminum dross) that were sintered at $1450^{\circ} \mathrm{C}$ exhibited the highest bending strength of $288 \mathrm{MPa}$ and bulk density $\left(3.15 \mathrm{~g} \cdot \mathrm{cm}^{-1}\right)$ and owned extremely low linear shrinkage (0.67\%). The presence of hazardous or impure elements was also investigated. The main impurity phase was $\mathrm{Fe}_{5} \mathrm{Si}_{3}$ containing $\mathrm{P}, \mathrm{Cr}, \mathrm{Mn}$, and Ni. Ca element was mostly incorporated into $\beta$-Sialon and less so into the glassy phase. Ti element was converted into TiN, which can improve the strength and wear resistance of the produced spinel- $\mathrm{Al}_{2} \mathrm{O}_{3}$-Sialon composites. This research may provide a new environmentally friendly approach to use the vast waste resources of fly ash and aluminum dross to produce low cost structural refractories.

\section{Conflict of Interests}

The authors have declared that no conflict of interests exists.

\section{Acknowledgments}

This work was financially supported by the National Natural Science Foundation of China (Grant no. 51032007) and the Fundamental Research Funds for Central Universities (Grant no. 2010ZD12).

\section{References}

[1] R. S. Iyer and J. A. Scott, "Power station fly ash-a review of value-added utilization outside of the construction industry," Resources, Conservation \& Recycling, vol. 31, no. 3, pp. 217-228, 2001. 
[2] O. M. Dunens, K. J. Mackenzie, and A. T. Harris, "Synthesis of multiwalled carbon nanotubes on fly ash derived catalysts," Environmental Science \& Technology, vol. 43, no. 20, pp. 78897894, 2009.

[3] F.-F. Zhu, M. Takaoka, K. Shiota, K. Oshita, and Y. Kitajima, "Chloride chemical form in various types of fly ash," Environmental Science \& Technology, vol. 42, no. 11, pp. 3932-3937, 2008.

[4] L. D. Hulett Jr., A. J. Weinberger, K. J. Northcutt, and M. Ferguson, "Chemical species in fly ash from coal-burning power plants," Science, vol. 210, no. 4476, pp. 1356-1358, 1980.

[5] T. Hashishin, Y. Kodera, T. Yamamoto, M. Ohyanagi, and Z. A. Munir, "Synthesis of $(\mathrm{Mg}, \mathrm{Si}) \mathrm{Al}_{2} \mathrm{O}_{4}$ spinel from aluminum dross," Journal of the American Ceramic Society, vol. 87, no. 3, pp. 496-499, 2004.

[6] E. David and J. Kopac, "Hydrolysis of aluminum dross material to achieve zero hazardous waste," Journal of Hazardous Materials, vol. 209-210, pp. 501-509, 2012.

[7] J. Johnson, “The foul side of 'clean coal', Chemical \& Engineering News, vol. 87, no. 8, pp. 44-47, 2009.

[8] A. Baba and A. Kaya, "Leaching characteristics of solid wastes from thermal power plants of western Turkey and comparison of toxicity methodologies," Journal of Environmental Management, vol. 73, no. 3, pp. 199-207, 2004.

[9] J. A. Borcherding, H. Chen, J. C. Caraballo et al., "Coal fly ash impairs airway antimicrobial peptides and increases bacterial growth," PLoS ONE, vol. 8, no. 2, Article ID e57673, 2013.

[10] S. B. Wang and H. W. Wu, "Environmental-benign utilisation of fly ash as low-cost adsorbents," Journal of Hazardous Materials, vol. 136, no. 3, pp. 482-501, 2006.

[11] J. Y. Hwang, X. Huang, and Z. Xu, "Recovery of metals from aluminum dross and saltcake," Journal of Minerals \& Materials Characterization \& Engineering, vol. 5, no. 1, pp. 47-62, 2006.

[12] M. C. Yusta, I. Mármol, J. Morales, and L. Sánchez, "Use of olive biomass fly ash in the preparation of environmentally friendly mortars," Environmental Science \& Technology, vol. 45, no. 16, pp. 6991-6996, 2011.

[13] J.-H. Li, H.-W. Ma, and W.-H. Huang, "Effect of $\mathrm{V}_{2} \mathrm{O}_{5}$ on the properties of mullite ceramics synthesized from highaluminum fly ash and bauxite," Journal of Hazardous Materials, vol. 166, no. 2-3, pp. 1535-1539, 2009.

[14] N. N. Sampathkumar, A. M. Umarji, and B. K. Chandrasekhar, "Synthesis of $\alpha$-cordierite (indialite) from flyash," Materials Research Bulletin, vol. 30, no. 9, pp. 1107-1114, 1995.

[15] M. Miyake, C. Tamura, and M. Matsuda, "Resource recovery of waste incineration fly ash: synthesis of zeolites A and P," Journal of the American Ceramic Society, vol. 85, no. 7, pp. 1873-1875, 2002.

[16] J.-T. Huang, Y.-G. Liu, Z.-H. Huang et al., "Ni( $\left(\mathrm{NO}_{3}\right)_{2}$-assisted catalytic synthesis and photoluminescence property of ultralong single crystal Sialon nanobelts," Crystal Growth \& Design, vol. 13, no. 1, pp. 10-14, 2013.

[17] F. L. Riley, "Silicon nitride and related materials," Journal of the American Ceramic Society, vol. 83, no. 2, pp. 245-265, 2000.

[18] Z.-H. Huang, J.-Z. Yang, Y.-G. Liu et al., "Novel sialon-based ceramics toughened by ferro-molybdenum alloy," Journal of the American Ceramic Society, vol. 95, no. 3, pp. 859-861, 2012.

[19] L.-H. Xu, F. Lian, H. Zhang, Y.-B. Bi, K. Cheng, and Y.-B. Qian, "Optimal design and preparation of beta-SiAlON multiphase materials from natural clay," Materials \& Design, vol. 27, no. 7, pp. 595-600, 2006.
[20] F. J. Li, T. Wakihara, J. Tatami, K. Komeya, T. Meguro, and K. J. D. MacKenzie, "Elucidation of the formation mechanism of $\beta$ SiAlON from a zeolite," Journal of the American Ceramic Society, vol. 90, no. 5, pp. 1541-1544, 2007.

[21] W.-W. Chen, P.-L. Wang, D.-Y. Chen et al., "Synthesis of $(\mathrm{Ca}, \mathrm{Mg})-\alpha$-sialon from slag by self, propagating hightemperature synthesis," Journal of Materials Chemistry, vol. 12, no. 4, pp. 1199-1202, 2002.

[22] J. E. Gilbert and A. Mosset, "Preparation of $\beta$-SiAlON from fly ashes," Materials Research Bulletin, vol. 33, no. 1, pp. 117-123, 1998.

[23] Y. Miyamoto, S. Kanehira, and M. Radwan, "Recycling of industrial and natural wastes to SiAlONs," Refractories Applications and News, vol. 9, no. 1, pp. 15-16, 2004.

[24] O. Yamamoto, M. Ishida, Y. Saitoh, T. Sasamoto, and S. Shimada, "Influence of $\mathrm{Mg}^{2+}$ on the formation of $\beta$-SiAlON by the carbothermal reduction-nitridation of homogeneous gel," International Journal of Inorganic Materials, vol. 3, no. 7, pp. 715719, 2001.

[25] G. H. Liu, K. X. Chen, H. P. Zhou, X. S. Ning, and J. M. F. Ferreira, "Effect of diluents and $\mathrm{NH}_{4} \mathrm{~F}$ additive on the combustion synthesis of $\mathrm{Yb} \alpha$-SiAlON," Journal of the European Ceramic Society, vol. 25, no. 14, pp. 3361-3366, 2005.

[26] K. Matsui, T. Yamakawa, M. Uehara, N. Enomoto, and J. Hojo, "Mechanism of alumina-enhanced sintering of fine zirconia powder: influence of alumina concentration on the initial stage sintering," Journal of the American Ceramic Society, vol. 91, no. 6, pp. 1888-1897, 2008.

[27] X. M. Feng, X. Q. Lian, M. X. Jiang, and Y. E. He, "The influences of TiN content on the properties of the in situ $\mathrm{Al}_{2} \mathrm{O}_{3}$ TiN composites," Advanced Materials Research, vol. 311-313, pp. 1906-1910, 2011.

[28] R. A. Janes, M. Aldissi, and R. B. Kaner, "Controlling surface area of titanium nitride using metathesis reactions," Chemistry of Materials, vol. 15, no. 23, pp. 4431-4435, 2003.

[29] Z. J. Peng, H. Z. Miao, L. H. Qi, S. Z. Yang, and C. Z. Liu, "Hard and wear-resistant titanium nitride coatings for cemented carbide cutting tools by pulsed high energy density plasma," Acta Materialia, vol. 51, no. 11, pp. 3085-3094, 2003.

[30] D. L. Ye and J. H. Hu, Practical Thermodynamics Data Handbook of Inorganic Substances, Metallurgical Industry Press, Beijing, China, 2002.

[31] Y. B. Cai, Z. J. Shen, J. Grins, and S. Esmaeilzadeh, "Sialon ceramics prepared by using $\mathrm{CaH}_{2}$ as a sintering additive," Journal of the American Ceramic Society, vol. 91, no. 9, pp. 29973004, 2008.

[32] K. Shizaki, S. Komarneni, and M. Nanko, Porous Materials: Process Technology and Applications, vol. 4 of Materials Technology Series, Kluwer Academic, Dordrecht, The Netherlands, 1998.

[33] D. L. Perry, Handbook of Inorganic Compounds, CRC Press, Boca Raton, Fla, USA, 2nd edition, 2011. 

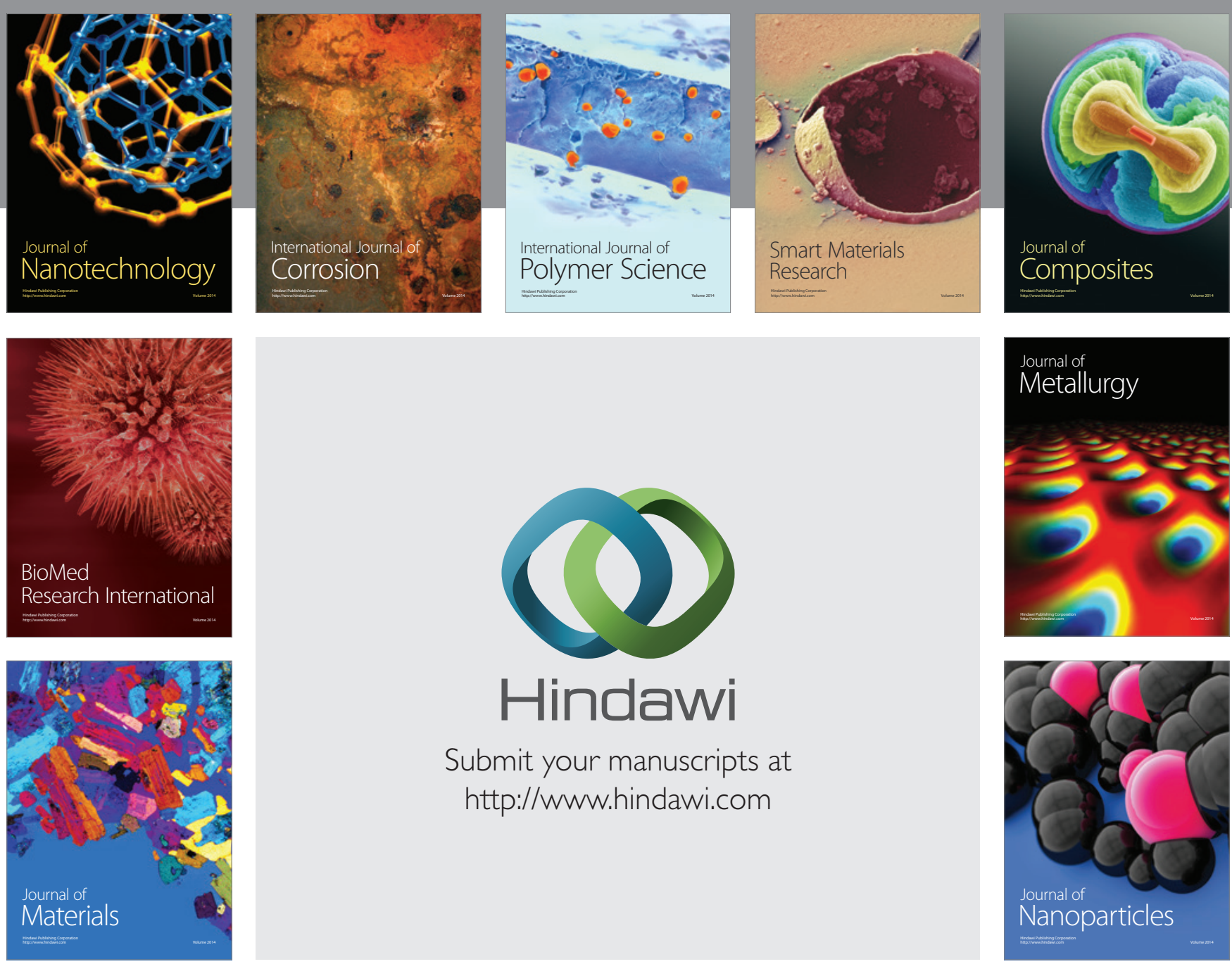

Submit your manuscripts at http://www.hindawi.com
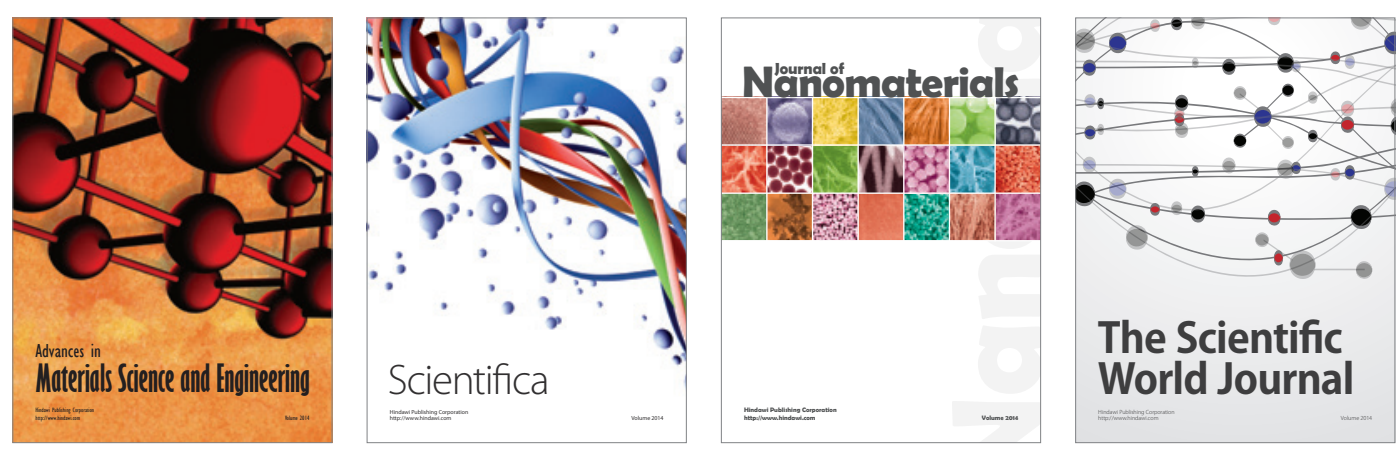

\section{The Scientific World Journal}
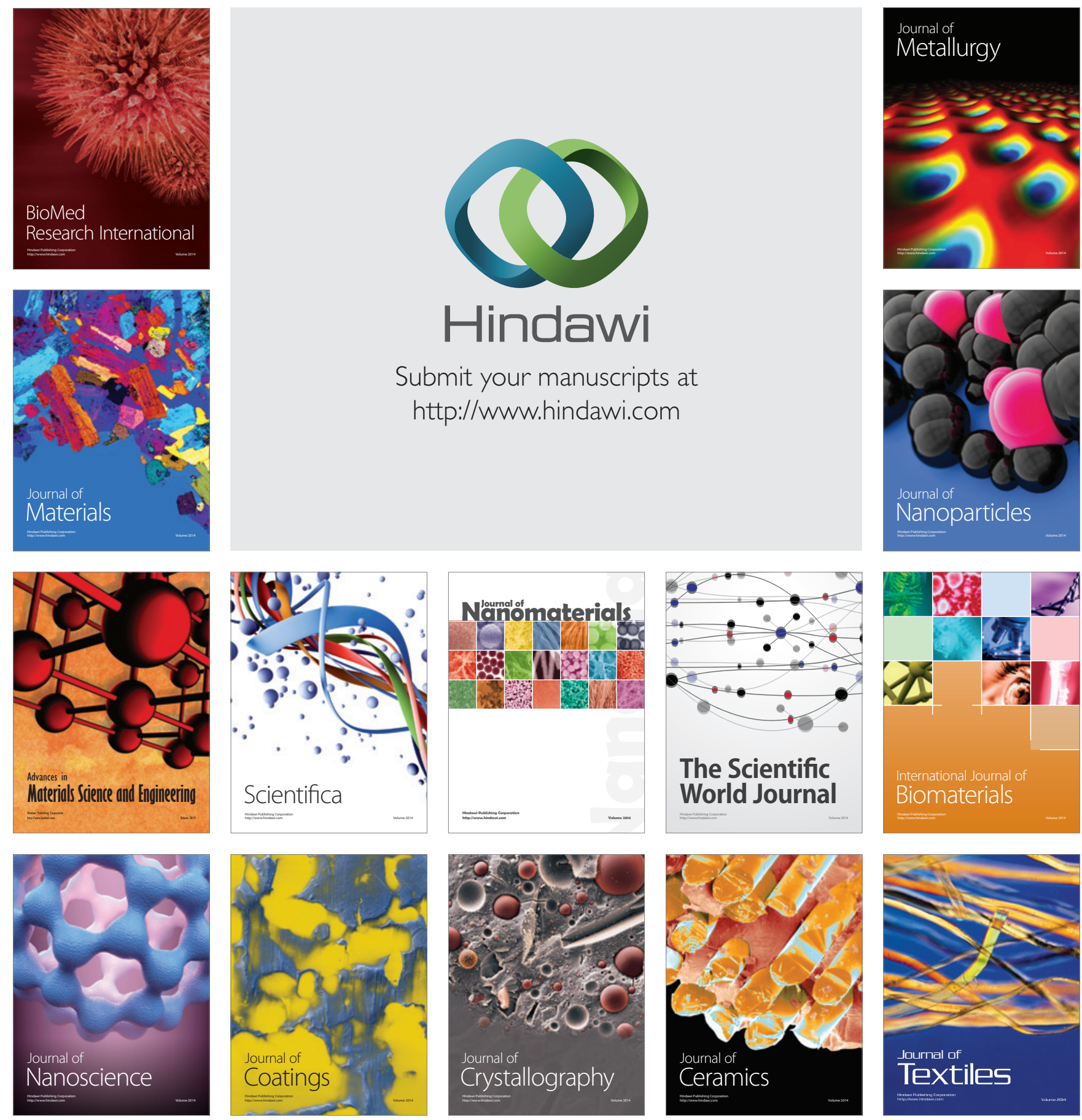